\title{
Diagnostic Utility of Ultrasound-Guided Core-Needle Biopsy Performed by a Head and Neck Surgeon for Mass Lesions with Inconclusive Result in Fine-Needle Aspiration Cytology
}

\author{
Hyun Ho Cho, Taehoon Kim, Jin Ho Sohn, and Dongbin Ahn \\ Department of Otolaryngology-Head and Neck Surgery, School of Medicine, Kyungpook National University, Daegu, Korea
}

\begin{abstract}
세침흡인검사로 진단되지 않은 종괴에 대해 두경부 외과의가 시행한 초음파 유도 하 중심바늘생검의 진단적 유용성
\end{abstract}

조현호 · 김태훈 · 손진호 · 안동빈

경북대학교 의학전문대학원 이비인후-두경부외과학교실

Received September 15, 2015

Revised November 4, 2015

Accepted November 9, 2015

Address for correspondence

Dongbin Ahn, MD

Department of Otolaryngology-

Head and Neck Surgery,

School of Medicine,

Kyungpook National University,

680 Gukchaebosang-ro, Jung-gu,

Daegu 41944, Korea

Tel $+82-53-200-2792$

Fax $+82-53-200-2027$

E-mail godlikeu@naver.com
Background and Objectives To evaluate the diagnostic utility of ultrasound (US)-guided core-needle biopsy (CNB) (US-CNB) performed by a head and neck surgeon for mass lesions with inconclusive result in previous fine-needle aspiration cytology (FNAC).

Subjects and Method Forty six patients who had previously inconclusive results of nondiagnostic specimen, undetermined significance, and malignancy/suspicious malignancy with undetermined subtype were included in the study. They were divided into the repeating FNAC (rFNAC) group and CNB groups. Procedure time, success of targeting, and complications were evaluated in the CNB group. In addition, the diagnostic utility of CNB was compared with that of FNAC.

Results US-CNB was successfully completed by a head and neck surgeon in all 23 cases without any major complications. The US-CNB group showed significantly lower rates of repeated non-diagnostic/undetermined results than in the rFNAC group ( $0 \%$ vs. $40.9 \%, p=0.001)$. In addition, CNB provided specific pathological diagnoses that permitted the surgeon to establish an appropriate treatment plan in $95.7 \%(22 / 23)$ of the CNB group, while rFNAC provided specific pathological diagnoses in $56.5 \%(13 / 23)$ of the rFNAC group $(p=0.002)$.

Conclusion US-CNB can be performed safely by head and neck surgeons, providing better diagnostic results compared with those of rFNAC for mass lesions with inconclusive results in previous FNAC.

Korean J Otorhinolaryngol-Head Neck Surg 2016;59(4):293-9

Key Words Core-needle biopsy · Fine-needle aspiration · Head and neck neoplasms · Ultrasound.

\section{서 론}

갑상선을 포함한 두경부 영역에 발생하는 종괴는 비교적 흔 히 나타나는 임상양상으로, 양성과 악성을 감별하는 것이 치 료를 계획하는 데 필수적이다. 이를 위해서는 치료 전 세침흡 인검사 또는 조직생검을 통한 병리학적 진단이 이루어져야 하
며, 이 중 세침흡인검사가 일차 검사법으로 널리 이용되고 있다. 2008년 Tandon 등이 30 개의 이전 연구를 검토하여 두경 부 종괴에 대해 시행된 3459예의 세침흡인검사를 분석한 연 구에 따르면, 검체를 충분히 획득한 경우 민감도 $89.6 \%$, 특이 도 $96.5 \%$, 그리고 정확도 $93.1 \%$ 로 세침흡인검사가 매우 우수한 술 전 병리진단법임을 보여주었다. 하지만 동시에 최대 $14.6 \%$ 
의 위음성율과 $20 \%$ 전후의 비진단적 검체(non-diagnostic specimen) 또는 미결정(undetermined) 결과를 보고하였으며, 이러한 경우 반복적인 세침흡인검사 또는 조직을 획득하기 위 한 추가적인 개방 생검이 필요하다고 하였다.) 하지만 비진단적 또는 미결정 결과를 보인 종괴에서 반복적인 세침흡인검사를 시행하였을 때에도 20 50\%에서는 여전히 비진단적 또는 미 결정의 결과를 보여 반복된 세침흡인검사만으로는 향후 치 료 방침을 결정하지 못하는 경우가 흔히 발생한다. ${ }^{2-4)}$ 이러한 경우 수술적 개방 생검이 종괴의 조직학적 진단을 위한 가장 정확한 방법이긴 하나, 피부 절개로 인한 흥터 및 전신마취나 입원과 관련된 불편감 등이 발생할 수 있다는 단점이 있다.5)

초음파 유도 하 중심바늘생검은 1993년 유방 종괴에 대해 소개된 이후, 1995년 Bearcroft 등이이 두경부 종괴의 진단에 있어서 그 유용성을 처음 발표하였으며, 현재까지 다양한 영 역에서 적용되어 세침흡인검사를 보완하고 수술적 개방 생 검을 대체할 수 있는 방법으로 주목받고 있다. ${ }^{2-4,6-10)}$ 하지만, 현재까지 대부분의 초음파 유도 하 중심바늘생검은 초음파 술기에 익숙한 영상의학과 의사에 의해 시행되었으며, 이러한 상황은 환자의 입장에서 보았을 때 외래 진료 후 시술을 위 해 다시 타 과를 방문해야 하는 번거로움과, 그에 따른 시간 소요 및 진료 비용의 증가가 불가피하게 된다. 이에 본 저자들 은 세침흡인검사에서 결정적 진단이 내려지지 않은 갑상선 및 림프절의 종괴에서, 술 전 2차 병리학적 검사로 두경부 외 과의에 의해 직접 시행되는 중심바늘생검의 기술적 가능성
과 진단적 유용성을 평가해보고자 하였다.

\section{대상 및 방법}

\section{대 상}

2013년 3월에서 2014년 5월까지 한 명의 두경부 외과의에 시행된 초음파유도 하 세침흡인검사에서 비진단적 검체의 소 견을 보이거나, 양악성 구분에 있어 미결정 결과를 보인 경우, 그리고 세포검사상 악성 또는 악성 의심의 소견을 보이지만 아형이 분류되지 않아(malignancy with undetermined subtype) 치료 방향 결정을 위해 추가적인 병리학적 검사가 요구 되는 환자 46 명을 대상으로 하였으며, 이 환자들에 대한 추가 병리학적 검사로 세침흡인검사를 반복 시행한 군 23명과 중심 바늘생검을 시행한 군 23 명의 진단 결과를 비교 분석하였다. 이번 연구는 저자들이 속한 기관의 임상시험심사위원회의 승 인을 받아 진행되었으며(등록번호 2014-10024), 본 연구에 포 함된 두 환자 군의 연령, 성별, 종괴의 위치(갑상선 또는 림프 절), 이전 세침흡인검사 결과의 분포, 종괴의 크기, 그리고 낭 성 변화 및 석회화 존재 여부 등의 초음파 소견에 있어서 통계 학적 차이는 없었다(Table 1).

\section{초음파 유도 하 세침흡인검사}

모든 초음파 유도 하 세침흡인검사는 중심바늘생검에서와 동일한 한 명의 두경부외과의에 의해 이비인후과 외래에서 시

Table 1. Basic clinicopathological characteristics of the repeat fine-needle aspiration cytology (rFNAC) and core-needle biopsy (CNB) groups

\begin{tabular}{|c|c|c|c|}
\hline Variables & rFNAC $(n=23)$ & CNB $(n=23)$ & $p$-value \\
\hline Age (years) & $53.3 \pm 14.0$ & $55.0 \pm 16.3$ & 0.700 \\
\hline Sex & & & 0.376 \\
\hline Men & $10(43.5 \%)$ & $13(56.5 \%)$ & \\
\hline Women & $13(56.5 \%)$ & $10(43.5 \%)$ & \\
\hline Location & & & 0.546 \\
\hline Thyroid gland & $15(65.2 \%)$ & $13(56.5 \%)$ & \\
\hline Lymph nodes & $8(34.8 \%)$ & $10(43.5 \%)$ & \\
\hline \multicolumn{4}{|l|}{ Previous FNAC results } \\
\hline Non-diagnostic & $10(43.5 \%)$ & $7(30.5 \%)$ & 0.359 \\
\hline Undetermined significance & $12(52.2 \%)$ & $13(56.5 \%)$ & 0.767 \\
\hline $\begin{array}{l}\text { Malignancy or suspicious malignancy } \\
\text { with undetermined subtype }\end{array}$ & $1(4.3 \%)$ & $3(13.0 \%)$ & 0.608 \\
\hline Mass size $(\mathrm{cm})$ & $1.3 \pm 0.8$ & $1.5 \pm 0.8$ & 0.419 \\
\hline \multicolumn{4}{|l|}{ Mass nature on ultrasound } \\
\hline Predominant solid & $20(87.0 \%)$ & $22(95.7 \%)$ & 0.608 \\
\hline Presence of calcification & $7(30.4 \%)$ & $9(39.1 \%)$ & 0.536 \\
\hline Micro-calcification & $1(4.3 \%)$ & $3(13.0 \%)$ & \\
\hline Macro-calcification & $2(8.7 \%)$ & $2(8.7 \%)$ & \\
\hline Rim-calcification & $4(17.4 \%)$ & $4(17.4 \%)$ & \\
\hline
\end{tabular}

FNAC: fine-needle aspiration cytology 
행되었다. 초음파 기구로는 HD7 Philips Ultrasound system (Philips Healthcare, Bothell, WA, USA)과 5 12 MHz의 탐 촉자(probe)가 사용되었으며, 대부분의 경우 1.5 inch 길이의 25 gauge 바늘을 이용하였으나, 종물이 매우 단단하거나 석회 화가 심하여 해당 바늘이 통과하지 못하는 경우는 보다 굵은 21 gauge 바늘을 사용하기도 하였다.

외래에서 환자를 앙와위로 눕힌 후 어깨 밑에 베개 등으로 받쳐 주어 경부를 충분히 신전시킨 상태에서 우선 초음파 검 사를 시행하였다. 초음파로 목표가 되는 병변이 확인되면 피 부에 바늘을 삽입하여 실시간 초음파 영상을 통해 바늘의 끝 이 종괴 내부에 위치하도록 하고, 이후 바늘을 왕복운동시키 면서 모세삼투압에 의해, 또는 필요시 음압을 걸어 바늘에 세 포가 채취되도록 하였다. 일반적으로 세포 채취는 2 3회 시행 하였고 각각의 검체는 두 장의 슬라이드에 겹쳐 도말하고 95\% 알코올에 고정시킨 후 병리학적 검사를 위해 의뢰하였다.

\section{초음파 유도 하 중심바늘생검}

세침흡인검사에서와 동일한 방법으로 초음파 검사를 시행 한 다음, 시술에 앞서 바늘이 삽입될 피부 및 바늘의 예상 진 행경로에 $1: 100000$ 에피네프린이 희석된 $1 \%$ 리도카인을 주사 하여 국소마취를 시행하였다. 중심바늘생검 기구로는 $1.1 \mathrm{~cm}$
전진길이 $(1.1 \mathrm{~cm}$ excursion length)를 갖는 18 gauge 굵기의 TSK Ace-cut(Creat Medic, Yokohama, Japan)을 사용하였 다(Fig. 1). 초음파 유도 하에 탐촉자와 평행하게 중심바늘을 삽입하여 그 끝이 병변에 접하거나 병변 내부로 진입되도록 진행시켰으며(Fig. 2A), $1.1 \mathrm{~cm}$ 의 전진길이가 있음을 고려하여 적절한 위치에서 첫 번째 유도 캐눌라(stylet cannula) 발사를 시행하였다(Fig. 2B). 이후 실시간 초음파 영상을 통해 중심바 늘의 검체 채취부(specimen notch)의 위치를 확인하면서 두 번째 절단 캐눌라(cutting cannula)를 발사하여 조직을 채취 하였다(Fig. 2C). 일반적으로 검체 채취는 2회 시행하였으나, 림프종이 의심되는 경우는 다양한 면역조직화학염색에 필요 한 충분한 조직을 획득하기 위해 3 회에 걸쳐 검체를 채취하였 다. 얻어진 검체는 $10 \%$ 포르말린 고정액에 즉시 보관하여 병 리조직학적 검사를 위해 의뢰하였다.

\section{관찰 항목 및 통계학적 분석}

두경부 외과의에 의해 시행된 초음파 유도 하 중심바늘생 검의 기술적 가능성을 평가하기 위해 중심바늘생검을 시행 받은 23 명의 환자에서 시술 시간을 측정하는 한편, 그와 관련 된 합병증에 대해 조사하였다. 그리고 2차 병리학적 검사로 세 침흡인검사를 시행한 환자 군과 중심바늘검사를 사용한 군에
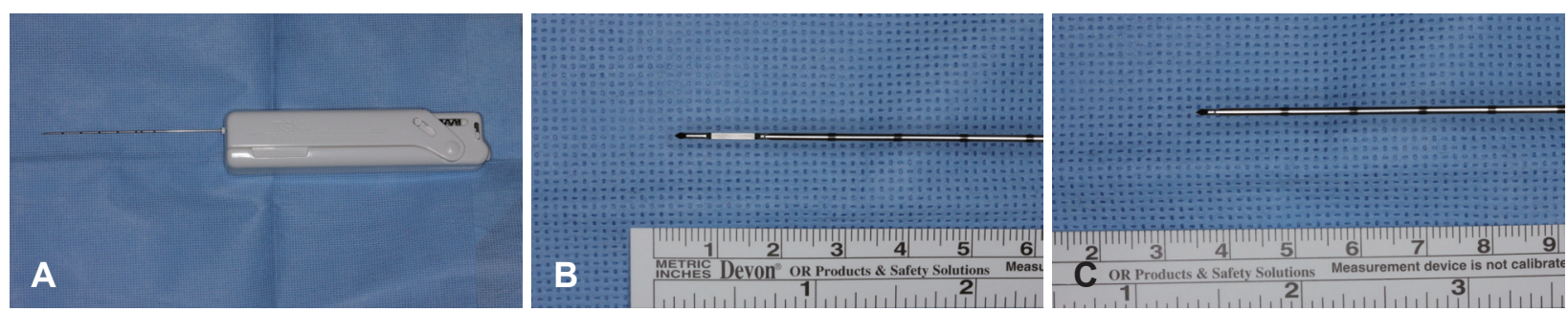

Fig. 1. Core-needle biopsy was performed using a disposable 18-gauge, double-action spring-activated needle with a 1.1-cm excursion length (TSK Ace-cut) (A). At the first firing, the stylet cannula of the needle advances with 1.1-cm excursion length (B). At the second firing, the cutting cannula advances over the specimen notch and tissue is harvested automatically $(C)$.
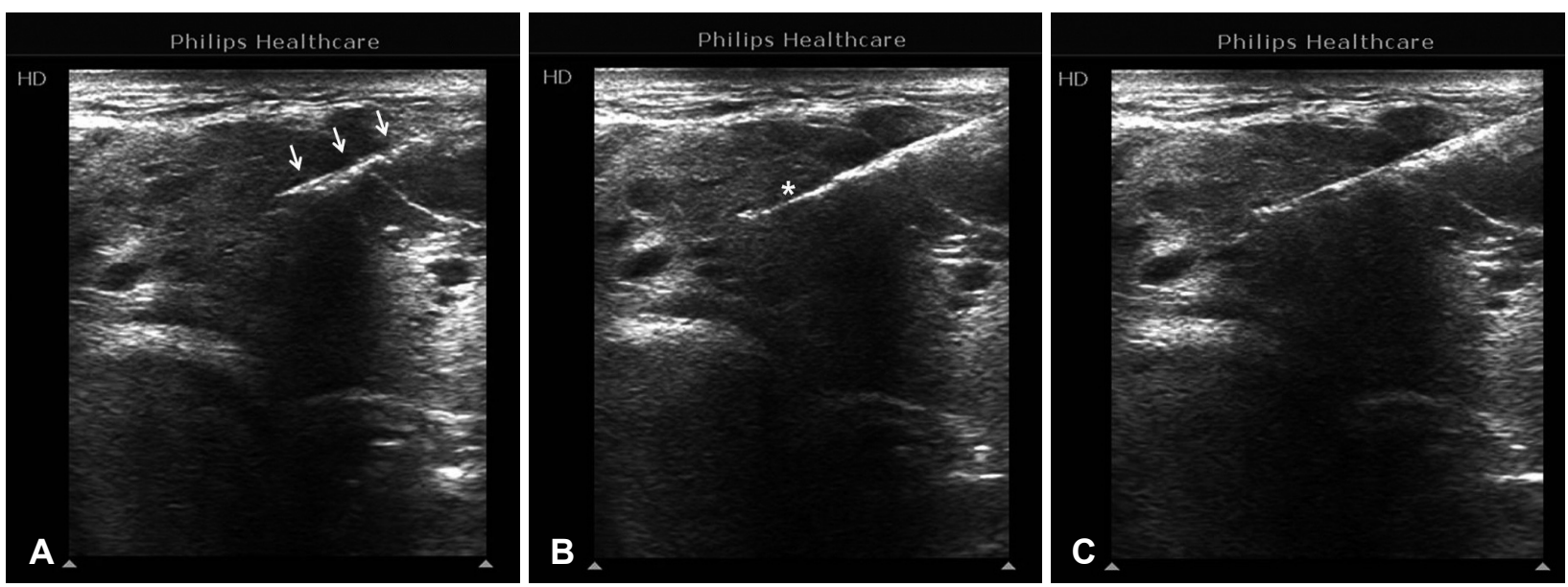

Fig. 2. The core needle (arrows) was inserted in the skin and advanced into the lesion (A). After confirming the biopsy route, the stylet was fired first exposing specimen notch (asterisk) (B), followed by the cutting cannula (C). 
서 반복적인 비진단적 검체 또는 미결정의 결과를 보인 비율 을 비교 분석하고, 각 군의 진단 결과를 첫 번째 세침흡인검사 의 결과와 비교하여 추가적인 진단적 유용성을 살펴보았다. 통계학적 분석은 SPSS(version 12.0; SPSS Inc., Chicago, IL, USA) 프로그램을 이용하여 연속형 변수에 대해서는 independent Student's t-test를, 범주형 변수에 대해서는 chi-square test 또는 Fisher's exact test를 사용하였으며, $p$ 값이 0.05 이하 인 경우를 통계학적으로 유의한 것으로 판단하였다.

\section{결 과}

\section{중심바늘생검의 기술적 가능성 및 합병증}

전체 23예를 대상으로 외래에서 초음파 유도 하 중심바늘 생검을 시행하는 데 소요된 시간은 평균 $6.3 \pm 1.6$ 분이었으며, 23예 모두에서 검체 채취가 성공적으로 이루어졌다. 시술과 관련된 통증이 10 명(43.4\%)에서 발생하여 가장 흔한 합병증으

Table 2. Feasibility and complication of ultrasound-guided coreneedle biopsy performed by head and neck surgeon

\begin{tabular}{lc}
\hline \multicolumn{1}{c}{ Variables } & Patients $(\mathrm{n}=23)$ \\
\hline Procedure time & $6.3 \pm 1.6 \mathrm{~min}$ \\
Target success & $23(100.0 \%)$ \\
Pain & $10(43.4 \%)$ \\
$\quad$ Visual Analogue Scale score & $0.7 \pm 1.0(0-3)$ \\
Hematoma or bleeding & 0 \\
$\quad$ Major or clinical & $5(21.7 \%)$ \\
$\quad$ Minor or subclinical & 0 \\
Recurrent laryngeal nerve injury & 0 \\
Tracheal injury & 0 \\
Esophageal injury & 0 \\
Cranial nerve injury & 0 \\
Numbness of the neck & \\
\hline
\end{tabular}

로 관찰되었으나, 그 정도는 Visual Analogue Scale 점수로 평 균 0.7점에 불과하였다. 또한 초음파에서만 관찰되는 무증상 의 소량 혈종이 5 예(21.7\%)에서 관찰되었으나 처치가 필요한 혈 종 또는 출혈은 관찰되지 않았으며, 반회후두신경을 포함한 신 경손상 및 식도와 기관의 손상 또한 발생하지 않았다(Table 2).

\section{반복적 세침흡인검사군}

이전 세침흡인검사에서 비진단적 결과를 보인 10예 중 7예 에서는 2차 세침흡인검사를 통해 적절한 검체 획득 및 양성(6 예) 또는 결핵성 림프절염(1예) 등의 치료 방향을 결정할 수 있 는 진단을 내릴 수 있었으며, 3예에서는 2차 세침흡인검사에 서도 반복적인 비진단적 검체의 결과를 나타내었다. 이전 세침 흡인검사에서 미결정 결과를 보인 12 예의 경우에는, 5 예는 양 성으로, 1 예는 아형을 알 수 없는 림프종 의심으로 진단되었으 나, 3예에서는 비진단적 검체의 소견을, 그리고 3예에서는 양 악성을 감별할 수 없는 미결정의 결과를 보였다. 그리고 이전 세침흡인검사에서 아형을 알 수 없는 악성 의심 소견을 보였 던 1예에서는 2차 세침흡인검사상 전이성 선암종 의심으로 진 단되었다(Fig. 3).

상기의 결과들을 종합하여 보면 전체 23예 중 1차 세침흡인 검사에서 아형을 알 수 없는 악성 의심의 소견을 보였던 1 예를 제외한, 22예의 비진단적 또는 미결정 결과 중 2차 세침흡인검 사를 통해 양악성의 감별이 가능하였던 경우는 13예(59.1\%)였 으며, 나머지 9예(40.9\%)의 경우는 2차례의 세침흡인검사에서 도 비진단적 또는 미결정의 결과가 나와 궁극적으로 종괴의 양악성 여부를 판단할 수 없었다.

\section{중심바늘생검군}

이전 세침흡인검사에서 비진단적 검체 소견을 보인 7예 모
Fig. 3. Diagnostic flow in the repeat fine-needle aspiration cytology and core-needle biopsy groups. FNAC: fine-needle aspiration cytology, rFNAC: repeat fine-needle aspiration cytology, CNB: core-needle biopsy, PTC: papillary thyroid carcinoma, LN: lymph node, TB: tuberculosis, SCCa: squamous cell cell carcinoma, Mets: metastasis, AdenoCa: adenocarcinoma, ATC: anaplastic thyroid carcinoma.

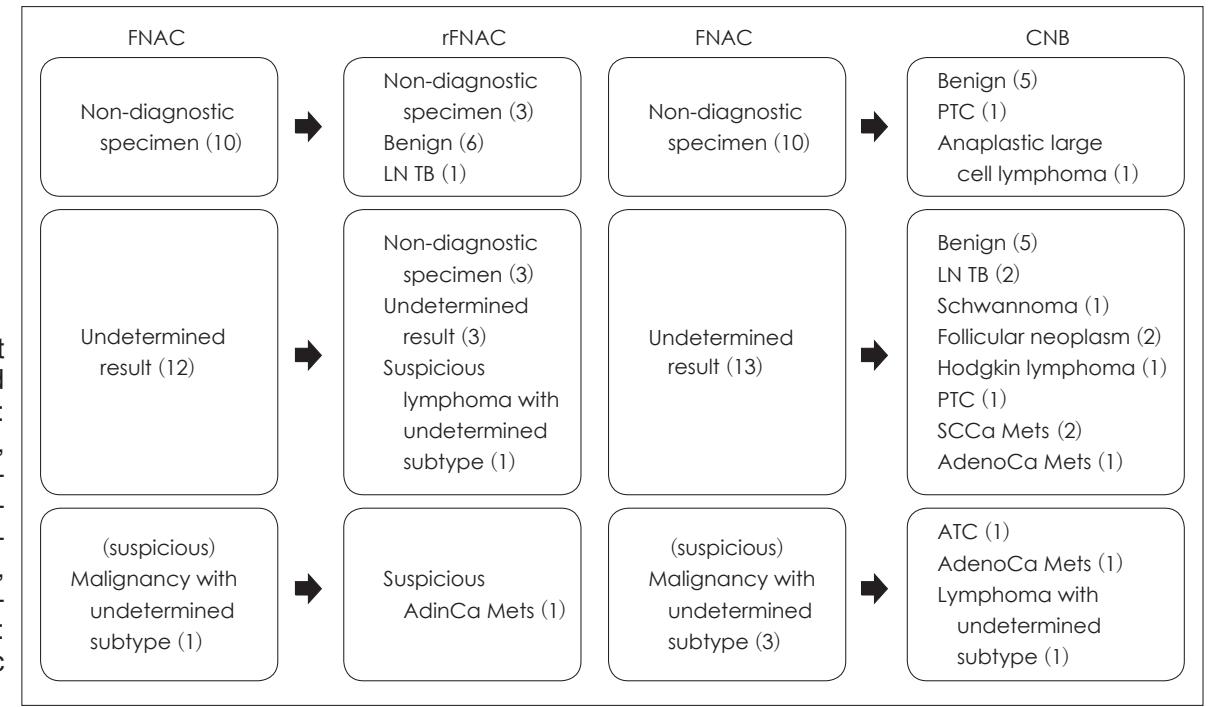


Diagnostic Utility of Ultrasound-Guided Core-Needle Biopsy I Cho HH, et al.

Table 3. Comparison of diagnostic results between the repeated fine-needle aspiration cytology (rFNAC) and core-needle biopsy (CNB) groups

\begin{tabular}{|c|c|c|c|}
\hline & rFNAC & CNB & p-value \\
\hline $\begin{array}{l}\text { Overall incidence of repeated non-diagnostic/undetermined } \\
\text { results/malignancy with undetermined subtype }\end{array}$ & $43.5 \%(10 / 23)$ & $4.3 \%(1 / 23)$ & 0.002 \\
\hline $\begin{array}{l}\text { Repeated non-diagnostic/undetermined results from previous } \\
\text { non-diagnostic/undetermined results }\end{array}$ & $40.9 \%(9 / 22)$ & $0 \%(0 / 20)$ & 0.001 \\
\hline Repeated non-diagnostic results from previous non-diagnostic results & $30 \%(3 / 10)$ & $0 \%(0 / 7)$ & 0.228 \\
\hline Repeated undetermined results from previous undetermined results & $25 \%(3 / 12)$ & $0 \%(0 / 13)$ & 0.096 \\
\hline $\begin{array}{l}\text { Specific pathological diagnoses that permitted the surgeon } \\
\text { to establish an appropriate treatment plan }\end{array}$ & $56.5 \%(13 / 23)$ & $95.7 \%(22 / 23)$ & 0.002 \\
\hline
\end{tabular}

두(100\%)에서 중심바늘생검을 통해 적절한 검체 획득이 이 루어졌으며, 이 중 5 예에서는 양성, 1 예서는 갑상선 유두암, 그 리고 1예에서는 역형성 큰 세포 림프종(anaplastic large cell lymphoma)의 결과를 보였다. 이전 세침흡인검사에서 미결정 의 결과를 보인 13예 모두에서도 중심바늘생검을 통해 적절 한 검체를 얻을 수 있었으며, 이 중 11예서는 양악성의 감별 및 악성일 경우 그 세부 아형까지 확인할 수 있었다. 나머지 2 예에서는 갑상선의 여포성 종양의 결과를 보여 중심바늘생검 만으로는 양악성 감별이 불가능하였다. 이전 세침흡인검사에 서 악성 또는 악성 의심의 소견을 보였지만 정확한 세부아형 을 알 수 없었던 3예의 경우, 2 예에서는 각각 미분화 갑상선암 과 전이성 선암종으로 진단되어 세부 아형에 대한 추가 정보를 얻을 수 있었고, 1 예에서는 림프종으로 진단되었으나 그 세부 아형은 특정할 수 없었다(Fig. 3).

상기의 결과들을 종합하여 보면 전체 23예 중 1차 세침흡인 검사에서 비진단적 또는 미결정 결과를 보였던 20예 중 반복 적으로 비진단적 또는 미결정의 결과를 보였던 경우는 없었으 며, 갑상선의 여포성 종양을 보인 2예를 제외하고는 모두에서 양악성의 감별이 가능하였다. 아형을 알 수 없는 악성 또는 악 성 의심의 소견을 보였던 3 예의 경우, 2 예에서는 그 세부아형 에 대한 확인이 가능하여 적합한 치료방침을 결정할 수 있었 는 데 반해, 1 예에서는 중심바늘생검을 통해 림프종이라는 진 단을 내릴 수는 있었으나 그 세부아형에 대한 추가 정보는 획 득할 수 없었다.

\section{반복적 세침흡인검사군과 중심바늘생검군의 진단적 유용성 비교}

반복적인 세침흡인검사군의 경우 반복적으로 비진단적 검 체 또는 미결정 결과, 그리고 아형이 결정되지 않은 악성의 소 견 등의 결과를 보여 정확한 치료 방침을 결정하기 어려윘던 경우는 10예(43.5\%)였던 것에 반해, 중심바늘생검군에서는 세 부아형이 결정되지 못한 림프종의 결과를 보인 1예(4.3\%)를 제 외한 22예(95.7\%)에서 중심바늘생검을 통해 적절한 치료 방 향을 결정할 수 있었으며, 이러한 차이는 통계학적으로 유의
하였다 $(p=0.002)$. 그리고 이전 세침흡인검사에서 비진단적 또 는 미결정 결과를 보인 종괴에서 반복적으로 비진단적 또는 미결정 결과를 보인 경우는 반복적인 세침흡인검사군에서 40.9\%(9/22), 중심바늘검사군에서 0\%(0/20)였으며, 이러한 차 이 역시 통계학적으로 유의하였다 $(p=0.001)$. 이전 세침흡인검 사에서 비진단적 결과를 보인 종괴에서 반복적으로 비진단적 결과를 보인 경우 및 이전 세침흡인검사에서 미결정 결과를 보인 종괴에서 반복적으로 미결정 결과를 보인 경우는 반복적 인 세침흡인검사군에서 각각 $30 \%(3 / 10)$ 와 $25 \%$ (3/12)였으나, 중심바늘생검군에서는 반복적으로 비진단적 결과나 미결정 결과를 보인 경우는 1 예도 없었다(Table 3). 하지만 이러한 차 이는 적은 대상수로 인해 통계학적으로 의미 있지는 않았다. 전체적으로 적절한 치료 방침 결정을 위한 특정 진단이 가능 하였던 비율은 반복적 세침흡인검사군에서 $56.5 \%(13 / 23)$, 중 심바늘생검군에서 $95.7 \%(22 / 23)$ 를 보여, 2차 병리검사로 중심 바늘생검을 시행한 환자군에서 통계학적으로 유의하게 높은 결과를 보였다 $(p=0.002)$.

\section{고 찰}

중심바늘생검은 수술적 개방 생검보다 덜 침습적이면서 세 침흡인검사에 비해 진단적 정확도가 높아 두경부 종괴의 진단 검사로 최근 주목받고 있으며, 그 유용성에 관한 연구들도 많 이 보고되고 있다. ${ }^{2-4,6-10)}$ 하지만 유방이나 간 등의 영역에서 임 상의가 직접 초음파 유도 하 중심바늘생검을 시행하는 것이 보편화된 것과는 달리, 두경부 영역에서는 아직 임상의에 의 해 직접 시행되는 중심바늘생검이 의료진 및 환자 모두에게 생소하며, 이에 대한 연구 또한 거의 이루어지지 않은 실정이 다. 저자들은 이번 연구를 통해 갑상선 및 림프절 종물에 대 한 초음파 유도 하 중심바늘생검이 두경부 외과의에게도 충 분히 기술적으로 가능한 시술임을 확인할 수 있었으며, 시술 소요시간 역시 평균 6.3분으로 2007년 Pfeiffer 등이에 의해 보고된 소요시간 15 20분과 비교하여서도 양호한 결과를 나 타내었다. 또한 이러한 시술을 시작함에 있어 가장 우려되는 
부분인 합병증에 있어서도, 치료나 관찰이 필요한 합병증은 발생하지 않음으로써 기존 영상의학과에서 보고한 결과들과 비교하여 차이를 보이지 않았다. ${ }^{11)}$ 이번 연구에는 이전 세침흡 인검사에서 비진단적 검체를 보인 환자들이 다수 포함되었음 에도 불구하고, 23명의 모든 중심바늘생검군 환자에서 2 3회 의 검체 채취를 통해 적절한 검체를 획득할 수 있었는데, 이 는 세침흡인검사를 반복적으로 시행한 경우와 비교하였을 때 통계학적으로 유의하게 낮은 비진단적 검체율이었다[0\% (0/23) vs. $26.1 \%(6 / 23), p=0.022]$. 또한 이러한 결과는 영상의 학과 의사에 의해 시행된 두경부 종괴의 초음파 유도 하 중심 바늘생검에 대한 이전 연구들에서 비진단적 검체 획득률이 $0 ~ 11.7 \%$ 인 것과 비교하였을 때도, 매우 양호한 결과임을 확 인할 수 있었다.1112) 사실 경부 종물에 대한 직접적인 환자 진 료와 수술을 담당하는 두경부외과의의 경우 실제 환자의 경 부 해부에 더 익숙하며, 이러한 점은 초음파에서 보이는 영상 학적 소견을 보다 잘 이해할 수 있는 장점이 된다. ${ }^{13)}$ 또한 해당 환자에서 수술을 시행하는 경우 술 전 두경부외과의가 직접 확인한 영상학적 소견을 술 중 실제 종양의 소견과 비교 분석 할 수 있기 때문에, 본인이 시행한 초음파 검사 및 관련 시술 에 대한 지속적인 피드백이 가능하게 된다. 이러한 점 때문에 초음파 유도 하 세침흡인검사의 경우 두경부외과의에 의해 이 미 많이 행해지고 있으며, ${ }^{13-16)}$ 중심바늘생검 역시 세침흡인검 사와 기술적으로 크게 다르지 않기 때문에 두경부외과의가 충분히 시도해볼 수 있을 것으로 생각된다.

현재 두경부 종괴의 병리학적 진단을 위한 일차 검사법으로 널리 이용되고 있는 세침흡인검사는 외래에서 비교적 간단하 고 신속하게 마취 없이 시행할 수 있고, 비용이 싸고 중요 합 병증의 위험 없이, 동시에 여러 부위를 검사할 수 있다는 장점 이 있다.1,7,18) 하지만 이전 세침흡인검사에서 비진단적 결과 또 는 미결정 결과를 보여 반복적인 세침흡인검사를 시행한 경우 20 50\%에서는 다시 비진단적 결과나 미결정 결과가 나타나 는 것으로 보고되고 있으며, 이러한 이유로 수 차례의 세침흡 인검사를 통해서도 치료 방침을 결정하지 못하는 경우가 종 종 발생하게 된다. ${ }^{2-4}$ 이번 연구에서도 1차 세침흡인검사로 비 진단적 또는 미결정 결과를 보인 22예 중 9예(40.9\%)에서는 2 차 세침흡인검사를 통해서도 반복적인 비진단적 또는 미결정 의 결과가 나와 적절한 치료 계획을 수립할 수 없었다. 이에 비 해 중심바늘검사군의 경우에는 이전 세침흡인검사에서 비진 단적 또는 미결정의 결과를 보인 갑상선 및 림프절의 종물에 있어서 갑상선의 여포성 종양으로 나온 2예를 제외한 모든 예 (90.0\%, 18/20)에서 양악성의 감별이 가능하였다. 갑상선의 여 포성 종양의 경우 궁극적으로 갑상선 절제술을 통한 조직검 사 이외의 방법으로는 양악성 감별이 불가능하다는 점을 고
려하면, 중심바늘생검을 통해 술 전 진단이 가능한 모든 예에 서 적절한 치료 계획을 수립할 수 있었다. 142 명의 세침흡인검 사 환자군과 54명의 중심바늘생검군이 포함된 Park 등의 븨 보 고에서도 이전 세침흡인검사에서 비진단적 또는 미결정 결과 가 나온 경우 반복적인 세침흡인검사를 통해 $48.6 \%$ 에서 다시 비진단적 또는 미결정 결과를 보인 반면, 중심바늘생검을 통 해 $1.8 \%$ 만이 다시 비진단적 또는 미결정의 결과를 보여, 저자 들의 이번 연구와 동일한 결과를 확인할 수 있었다. 이에 더하 여, 이번 연구에서 세침흡인검사에서 악성 또는 악성 의심의 소견을 보이지만 아형이 분류되지 않아 2차 병리학적 검사를 시행한 경우까지 포함하더라도 중심바늘생검군의 경우 23 명 중 22명(95.7\%)에서 치료 방향을 결정짓는 병리학적 진단이 이루어진 것에 반해, 반복된 세침흡인검사군의 경우 23 명 중 13 명(56.5\%)에서만 이러한 진단이 가능하여 나머지 10 명의 환 자에 대해서는 결국 추가적인 조직검사가 요구되었다.

이처럼 초음파 유도 하 중심바늘생검이 매우 우수한 진단 적 결과를 보여줌에도 불구하고, 아직 두경부 종괴에 대한 1 차 검사법으로 인정되지는 못하고 있는데, 이는 중심바늘생검 이 모든 환자에게서 기술적으로 가능한 것은 아니며, 시술을 위해서는 반드시 국소마취가 필요하고, 또한 이론적으로는 세 침흡인검사에 비해 출혈이나 통증을 유발할 가능성이 높다는 단점들 때문이다. 특히, 세침흡인검사와는 달리 중심바늘생검 의 경우 시술 기구의 특성상 조직검사 시 $1.1 \sim 2.2 \mathrm{~cm}$ 길이의 전진 바늘이 발사되기 때문에 그에 따른 바늘 발사 위치의 조 정 및 후방 구조에 대한 충분한 안전거리 확보가 필요하다. 만 약 이에 대한 이해가 부족할 경우 전진 바늘이 결절을 관통한 후 갑상선 후방이나 측방에 있는 기관, 식도, 반회후두신경, 경동맥 및 경정맥 등의 구조에 손상을 가할 수 있음을 반드시 주의하여야 한다.

본 연구에는 몇 가지 제한점이 있다. 우선 첫 번째 세침흡인 검사에서 비진단적 또는 미결정 결과가 나온 경우, 두 번째 병 리검사로 반복적 세침흡인검사와 중심바늘생검을 함께 시행 하여 동일한 환자군에서 비교 분석한 것이 아니라, 환자군을 각각 반복적 세침흡인검사군과 중심바늘생검군으로 나누어 비교 분석하였기 때문에, 비록 통계학적으로 유의하지는 않았 지만 그에 따른 대상 환자군 간의 차이가 있을 수 있다. 또한 반복적 세침흡인검사군과 중심바늘생검군의 대상 환자수가 각각 23명으로 적어, 민감도, 특이도, 양성예측도, 음성예측도 등의 진단적 정확도를 비교 평가하기에는 한계가 있었다. 하지 만 이러한 제한점에도 불구하고, 이번 연구는 두경부외과의에 시행되는 초음파 유도 하 중심바늘생검의 유용성에 대한 예 비 연구로서의 가치는 충분히 가질 수 있을 것으로 생각하는 바이다. 
결론적으로, 저자들은 본 연구를 통해 초음파 유도 하 중심 바늘생검이 두경부외과의에 의해서도 충분히 기술적으로 가 능하며, 검체 획득율 및 진단적 유용성 측면에서도 이전 영상 의학과에서 시행된 연구들에 준하는 결과를 얻을 수 있음을 확인하였다. 물론 이번 연구만을 통해 두경부외과의가 직접 시행하는 중심바늘생검이 보편화될 수는 없겠으나, 보다 많은 두경부외과의들이 경부 종괴의 치료뿐만 아니라 이러한 진단 과정에 적극적으로 관여함으로써 이비인후과 진료 영역이 보 다 확장되는 계기가 될 수 있을 것으로 생각되며, 궁극적으로 이러한 변화가 종괴의 진단을 위해 여러 과를 방문해야 하는 환자의 불편감을 해소하고, 진단 및 치료 시기를 앞당기는 데 기여할 수 있을 것으로 생각하는 바이다.

\section{REFERENCES}

1) Tandon S, Shahab R, Benton JI, Ghosh SK, Sheard J, Jones TM. Fine-needle aspiration cytology in a regional head and neck cancer center: comparison with a systematic review and meta-analysis. Head Neck 2008;30(9):1246-52.

2) Na DG, Kim JH, Sung JY, Baek JH, Jung KC, Lee H, et al. Coreneedle biopsy is more useful than repeat fine-needle aspiration in thyroid nodules read as nondiagnostic or atypia of undetermined significance by the Bethesda system for reporting thyroid cytopathology. Thyroid 2012;22(5):468-75.

3) Park KT, Ahn SH, Mo JH, Park YJ, Park do J, Choi SI, et al. Role of core needle biopsy and ultrasonographic finding in management of indeterminate thyroid nodules. Head Neck 2011;33(2):160-5.

4) Bowyer DJ, Smillie I, Ganly I. Diagnostic utility of freehand coreneedle biopsy in head and neck masses. J Laryngol Otol 2013;127 (2):175-80.

5) Kleid S, Millar HS. The case against open neck biopsy. Aust N Z J Surg 1993;63(9):678-81.

6) Bearcroft PW, Berman LH, Grant J. The use of ultrasound-guided cutting-needle biopsy in the neck. Clin Radiol 1995;50(10):690-5.

7) Bain G, Bearcroft PW, Berman LH, Grant JW. The use of ultrasound- guided cutting-needle biopsy in paediatric neck masses. Eur Radiol 2000;10(3):512-5

8) Ridder GJ, Technau-Ihling K, Boedeker CC. Ultrasound-guided cutting needle biopsy in the diagnosis of head and neck masses. Laryngoscope 2005;115(2):376-7.

9) Howlett DC, Menezes L, Bell DJ, Ahmed I, Witcher T, Bhatti N, et al. Ultrasound-guided core biopsy for the diagnosis of lumps in the neck: results in 82 patients. Br J Oral Maxillofac Surg 2006;44(1): 34-7.

10) Pfeiffer J, Kayser G, Technau-Ihling K, Boedeker CC, Ridder GJ. Ultrasound-guided core-needle biopsy in the diagnosis of head and neck masses: indications, technique, and results. Head Neck 2007; 29(11):1033-40.

11) Screaton NJ, Berman LH, Grant JW. Head and neck lymphadenopathy: evaluation with US-guided cutting-needle biopsy. Radiology 2002; 224(1):75-81.

12) Novoa E, Gürtler N, Arnoux A, Kraft M. Role of ultrasound-guided core-needle biopsy in the assessment of head and neck lesions: a meta-analysis and systematic review of the literature. Head Neck 2012;34(10):1497-503.

13) Karadeniz Cakmak G, Emre AU, Tascilar O, Gultekin FA, Ozdamar SO, Comert M. Diagnostic adequacy of surgeon-performed ultrasound-guided fine needle aspiration biopsy of thyroid nodules. J Surg Oncol 2013;107(2):206-10.

14) Robitschek J, Straub M, Wirtz E, Klem C, Sniezek J. Diagnostic efficacy of surgeon-performed ultrasound-guided fine needle aspiration: a randomized controlled trial. Otolaryngol Head Neck Surg 2010;142(3):306-9.

15) Al-azawi D, Mann GB, Judson RT, Miller JA. Endocrine surgeonperformed US guided thyroid FNAC is accurate and efficient. World J Surg 2012;36(8):1947-52.

16) Bohacek L, Milas M, Mitchell J, Siperstein A, Berber E. Diagnostic accuracy of surgeon-performed ultrasound-guided fine-needle aspiration of thyroid nodules. Ann Surg Oncol 2012;19(1):45-51.

17) Murthy P, Laing MR, Palmer TJ. Fine needle aspiration cytology of head and neck lesions: an early experience. J R Coll Surg Edinb 1997;42(5):341-6.

18) Bajaj Y, De M, Thompson A. Fine needle aspiration cytology in diagnosis and management of thyroid disease. J Laryngol Otol 2006; 120(6):467-9. 